\title{
Public Administration Reform over Time - Did Change Lead to a More Effective Integrity Management?
}

\author{
Christoph Demmke \\ University of Vaasa, Finland \\ demmke@outlook.de \\ https://orcid.org/0000-0001-6589-3127
}

Received: 18. 6. 2020

Accepted: 5. 10.2020

\section{ABSTRACT}

The following discussion adds to the discourse regarding the relationship between public administration reform and ethics policies. In this theoretical paper, a narrative is employed that re-reads the old Weberian model as a model of 'institutional integrity', which is slowly replaced by a public management concept that focuses on individual integrity. Whereas the Weberian concept defined institutional integrity as a quality of institutions, more recent management concepts define institutional integrity as a quality of public officers within institutions. This also explains why the current focus of attention is ever more on individuals (as the main cause for unethical conduct) and the bad-person model of integrity. An alternative framing of this paper is about 'institutional ethics' over time. During the last decades, we are moving from an institutional, but mechanical and rigid Weberian model, to an individual, but more fluid New Public Management model. We are moving towards a version of institutional integrity that tries to use new behavioural mechanism to get back to some Weberian virtues, without its structures and technical focus. This novel 'integrity management' movement is really all about filling the gaps left by New Public Management doctrines. However, the reform of integrity management also develops into a specialised, sophisticated and professionalised ethics bureaucracy. Trends are towards ever more broader and stricter integrity requirements. Still, ethics policies are ineffective and shortcomings in implementing integrity policies are neglected.

Keywords: integrity management, ethics, bureaucracy, public management reform, behavioural policies

JEL: M 48, 038 


\section{Introduction and research question}

Originally, this paper started as a desk-research paper at the University of Oxford (Blavatnik School of Government). The intention was to analyze the link between public management reform and ethics management reforms. How did the reform process changed the conceptualization of ethics policies and ethics management? How did the institutionalisation of ethics policies changed? Have ethics policies become more effective over time? And - which role and importance is allocated to individuals and which role to institutions? As the paper evolved, we also decided to use empirical insights from one of the most comprehensive empirical studies about the effectiveness of ethics policies and the institutionalization of ethics in the European Union (European Parliament, 2020). This study was carried out by the author in the year 2020. Overall, 18 Member States of the European Union contributed to the survey. The objective of the study was to survey and compare policies and implementation practices where they exist. Apart from this task, another objective was to discuss the emergence of integrity policies as a political topic with growing importance and the increasing difficulties to manage and to institutionalise ethics policies. Overall, the study concludes that current integrity policies are highly ineffective, despite the expansion of ethics policies and developments towards the emergence of a new ethics bureaucracy throughout the last years. There is no place here to further discuss the study in detail. As such, in this paper, we are interested in the (theoretical) interpretation of the results: Why are current integrity policies not more effective than traditional integrity policies? How did our understanding of ethics policies and the institutionalisation of ethics policies change over time - and why?

\section{The weberian bureaucratic model as model of institutional integrity}

Organizational theory claims that organizational settings influence people's way of thinking and their behaviour, and hence the content of public policy. Therefore, an organizational theory approach of integrity policies assumes that it is impossible to understand integrity policies without the way public institutions work and without analysing how they are organized and their modes of working (Christensen, Laegreid and Rovik, 2020, p.1). Following this, institutional integrity can be defined as a quality of institutions that is supposed to promote the quality of public employees. Starting from this definition, we suggest to re-read the bureaucratic model as the first (ineffective) institutional model of 'institutional integrity'. This (failed) model is being replaced by highly professional integrity policies that are not integrated into new institutional logics.

In most countries worldwide, public institutions were created as distinct structures with the objective of making the public sector independent from the private sector and public officials independent from personal and political in- 
terests. Originally, modern public institutions were conceptualized as rational machines which had democratic and ethical tasks of serving the society and the law, protect citizens, operate equitably and impartial. In almost all countries, constitutions, public organisations and civil service acts resulted in provisions that were loaded with legal obligations, values and principles and the need to have neutral, loyal and impartial state servants with very specific employment conditions and institutional features. This technical, legalistic and bureaucratic compliance and "ethics of neutrality" concept (Thompson, 1985) dominated until late in the 20st century. Traditional administrative theory also supported the view that administration should be a neutral body and separated from political interests. Some parts of these doctrines have survived until today: Experts still discuss how "policy capture" (defined as situations where public decisions over policies are consistently directed away from the public interest towards a specific interests) and can be avoided (OECD, 2017).

Still, one of the remnant of former times is that all countries share the understanding that no other institutional actor other than the public actor can combine public values such as expertise, continuity, professionalism, impartiality, equity, non-discrimination and fairness (van der Meer, Raadschelders and Toonen, 2015, p. 369; OECD, 2019).

Because of the specific ethical importance of certain state tasks, most countries are also reluctant to totally reverse, modify or change the specific institutional and employment features founded in the $19^{\text {th }}$ century in order to protect the democratic liberal state. Bekke \& van der Меer (2001) define modern public institutions as depersonalised systems which differ from traditional modes of "personalised" government. In the $19^{\text {th }}$ century, the biggest changes included the introduction of centralized recruitment procedures, the adoption of civil service laws, the centralization of HR policies and the introduction of merit principles (including entrance examinations, job tenure, career service, political neutrality) which were adopted - as a moral guardian to democracy - and which should shield employees from politically inspired employment actions. Consequently, almost all countries designed their public organizations in specific ways because they expected a certain ethical behavior on the part of civil servants would result from specific organizational features. In the United States, according to Anechiarico and Jacobs (1996, p. 22), the progressive reform movement and the scientific administration reformers believed that government integrity would flow from sound administration. Therefore, in a next step (and well within the $20^{\text {th }}$ century), countries introduced hierarchical organizational structures, scientific management methods, clear and rigid career paths, life-time tenure, full-time employment, seniority, advantageous pension systems and rigid remuneration systems in order to reduce as far as possible the risk of too much political influence, corruption, misconduct, the exercise of private interests and state capture for private interests. Administrative behavior was to follow hierarchical principles and doctrines which were based on the rule of law. Following this, at a minimal level, administration was considered to be good and ethical if it achieved the implementation and enforcement of the existing laws and policy goals of 
the Government of the day. Moreover, ethically good or acceptable behavior was also defined in terms of rationality, impartiality and standardization.

For a long time, experts were convinced that these specific organizational structures, principles and compliance approaches implicitly "produce" a certain personality (Merton, 1987), public service ethos, and "public service motivation" for civil servants who - in exchange - would be committed to the public good, neutrality, impartiality and displaying expertise. Thus, the concept of a bureaucratic organizational structure was to produce a certain ethical climate and the commitment to the public good, neutrality, impartiality and to observing confidentiality and displaying expertise. Bureaucracy was a synonym for institutional integrity (Demmke, 2019). It was the last existing coherent institutional integrity concept, at least in theory. Until today, this traditional rational, technical and instrumental understanding of public institution and integrity has not completely vanished. Instead, whatever is the correct diagnosis of current reform trends, it is worth noting that until today, no government has completely abolished all bureaucratic features. Moreover, no government has privatized the delivery of public tasks, no public administration works like a private company, and no public institutional system entirely emulates private sector practices. Therefore, in all countries worldwide, despite ongoing reforms, Government institutional frameworks are still perceived as being different compared to private sector features. Institutional regimes based on the rule of law, impartiality, merit and freedom of the media and justice (should) offer constraints upon corrupt and arbitrary political power (Lane, 2014).

However, as we will see, almost all of these traditional "bureaucratic" and "integrity" features are about to change bureaucratic structures, distinctions between the public and private sphere, legal and institutional principles and values and (rational) logics. With very uncertain outcomes.

\section{Why countries started to deviate from the traditional government models?}

When looking back, the traditional technical, legalistic and bureaucratic compliance and ethics of neutrality (Thompson, 1985) approach was very influential until at least the 1970's. "Bureaucracy was the model of public administration admired by Woodrow Wilson and other Progressives precisely because it promised to be an antidote to the corrupt spoils system" (Anechiarico and Jacobs, 1996, p. 173).

However, increasingly, almost all countries started to deviate from the classical bureaucratic model, because the concept underperformed on several fronts and not only as regards the classical dysfunctions of the classical bureaucratic model (too costly, discriminatory, too rigid, too hierarchical, not innovative, not performing, de-motivating effects). According to Anechiarico and Jacobs, "Public administration did not become professionalized like law and medicine" (Anechiarico and Jacobs, 1996, p. 21). Another problem with the concept of bureaucracy is, because as an ethical guideline, it is simply too narrow for to- 
day's multi-level governance. Especially the importance of individuals was neglected because of the focus on the concept of "administrative neutrality" and the dominance of rational and legal approaches. Today, trends are towards the opposite and the growing importance of individuals. Insights from behavioral economy and motivation theory have indeed shown that work in the public sector is more value-laden and more unpredictable than ever.

Public institutions are also subject of changes, not only as a result of rational-, financial- and technological pressures but also as a result of changing attitudes, norms, fashions, changing cognitive-cultural patterns (Di Maggio and Powell, 1983). This change process not only challenges rational choice theories and emphasizes the role of values, norms, structures and processes - and people. Instead, it also changes the classical (at least in theory) coherent relationship between bureaucratic features and integrity. Today, institutional features are separated from integrity features. Modern integrity policies have become a proper public policy and current developments in the field of public management have expanded the meaning, importance and the practical expression of the concept of integrity policies and integrity management. Overall, integrity management is not only becoming more professional, better institutionalized, complex and costly. Instead, managerial instruments like value management, purpose driven management and value-scorecard's are also becoming a fashion (in the sense of sociological institutionalism and isomorphism). As a result, the concept of integrity management develops into a popular, distinctive, specialized, sophisticated and professionalized policy that fills the ethical gaps that new management logics produce.

Still, it is difficult to say whether integrity management has also become more effective. Often, it seems, integrity policies are adopted as a reaction to mediated political scandals and because these policies are "cheap" and their implementation and monitoring is weak. Overall, integrity policies and integrity management can also be characterized as self-reinforcing processes that are highly change resistant and continue to follow the logic of ever more and ever stricter policies (Saint-Martin, 2006, p. 17). Change resistant means that it is simply impossible to call for a deregulation of ethics policies in certain areas, or - sometimes - even to criticize the ineffectiveness of chosen approaches. All of these trends, in turn, create a number of integrity-paradoxes (Nieuwenburg, 2007) such as the emergence of an ethics bureaucracy in times of de-bureaucratisation, attempts to enhance trust but - often - rising levels of distrust as a result. If in the past, there were seen to be regulatory gaps and a lack of enforcement, the more recent concern is that some governments have gone overboard in building an elaborate ethics apparatus that reflects the prevailing negative assumptions about the motivations and capabilities of both politicians and public servants. Today, trying to be ethical in every sense of the word, could mean that public organizations and their leaders end up pleasing no one.

Until today, there is indeed no evidence that bureaucratic structures have produced the intended integrity results. Evidence is growing that specific public working conditions and bureaucratic structures did not necessarily produce 
less corruption and a specific public service ethos. Dahlström and Lapuente (Dahlström and Lapuente, 2017) examine the existing link between bureaucratic structures and corruption. Both authors also conclude that closed bureaucracies are negatively related to the quality of governance. In "The Merit of Meritocratization: Politics, Bureaucracy, and the Institutional Deterrents of Corruption" Dahlström et al (Dahlström et al., 2012; see also Rauch and Evans, 2000) concluded that only some factors (most notably the meritocratic recruitment of public employees) exert a significant influence on curbing corruption even when controlling for the impact of most standard political variables. Also, the above-mentioned study for the European Parliament concludes that bureaucratic countries have more ethics rules in place than nonbureaucratic countries. However, there is no evidence to suggest that more rules are also more effective.

In Unmasking Administrative Evil, Adams and Balfour (1998) developed the concept of administrative evil in connection with a modernized society and an administrative culture dominated by technical rationality. According to the authors, the Holocaust was only possible in a perfect system of extreme obedience, loyalty and technical rationality. Today, it is claimed that also institutions (as well as individuals) have responsibilities, rights and duties. For example, public institutions have the duty to contribute to public values. Institutions also have a corporate purpose. Thus, when rephrasing Milton Friedman's claim that "The Social Responsibility of Business is to Increase Its Profits" (Friedman, 1970) this looks as follows in the case of public institutions: The Social Responsibility of Public Institutions is to serve public values.

Because of these many shortcomings, de-bureaucratization trends continue worldwide. However, there is no common trend towards an alternative universal administrative model. Rather, current reform modes are caught in an identity crisis. Countries know well what they want to leave behind. But they do not know where to go. There is - differently to what neo-institutionalists expected - no "isomorphism" logic and no trend towards a best-practice model. During the last decades, all countries worldwide have implemented new reforms, which have been successively defined as governance reforms leading to collaborative governance, a networking society, a co-production society, shared governance society, a digital-, or blockchaining society, or, even towards the partial return of a strong state, the Leviathan. In the meantime, we seem to be living in an era of flexible post-bureaucratic governance. In this scenario, government policy styles and public institutional reforms proceed from policy to policy and from sector to sector. Also the varieties of postbureaucratic governance or New Public Management have been challenged owing to the focus on results and cost savings (Hood and Dixon, 2013), compounded by the tendency to downplay the importance of other values and principles such as quality, fairness, equality, and impartiality. According to Andersson (2019), NPM reforms did not live up to expectations (Kolthoff, 2007):

- First, evidence is mixed regarding if performance has improved or costs dropped, 
- Second, the democratic nature of public administration was affected as the role of public service consumer substituted the role of citizens,

- Third, fairness as measured by service user's perceptions seem to have worsen

- Fourth, in many cases vulnerability for corruption increased (Andersson, 2019, p. 9).

Thus, whereas the traditional bureaucratic model is dismissed for many reasons, the emerging institutional models (such as the new public management model) lack any integrated and implicit integrity logic. Consequently, many countries started to invest in new value-based integrity policies, ethics infrastructures and the institutionalisation of ethics in order to compensate for the integrity gaps that the emerging institutional and managerial logics produced. Anecharico and Jacobs (1996, p. 239) define this as the birth of a "panoptic vision" of integrity policies. "They have gone beyond the political, legal, and institutional legacies of their predecessors (...). The contemporary reformers adopt or invent technologies, institutions, and routines to monitor public employees closely" (Anecharico and Jacobs, 1996, p. 23). From here, the concept of institutional integrity developed into a policy. Also, the link between institutional design and integrity is changing. Whereas the traditional bureaucratic understanding supported the view that institutional design matters for individual integrity, examining today's institutions from the "perspective of bounded rationality leads quickly to the understanding that the cognitive architectures of individuals affect the institutions they inhabit" (Shannon, McGee and Jones, 2019). And, not vice versa, as previously.

\section{Beyond the new "old" public management: Institutional logics and new complexities}

In the new public management context, traditional features like standardized procedures and the focus of law, regulation and administrative law are often seen as constraints that block policy choices, innovation, competition and individualism. Traditional administrative behaviour is held to be rigid, rulebound, centralised and obsessed with dictating how things should be done - regulating the process, controlling the inputs - but ignoring the end results. In this perspective, legalism is seen as cold, rational and restricting individual discretion. Consequently, emerging public management models supported a certain decline of established "legalistic" principles that - originally - were established in civil service acts and enshrined in many constitutions.

Parallel to these developments, concepts and theories in the fields of organizational theory, organizational behavior, organizational justice, strategic management, ethics, leadership and HRM (including engagement and motivation theories), have grown in complexity. Within these trends, values and emotions play an increasing role, such as value-based management, purpose driven management, or - in the private sector, corporate social responsibility. Compared to the traditional bureaucratic concept of integrity, it is fair to con- 
clude that, "there has been an "affective revolution" in public management since the mid-1990s, focusing initially on new behavioral insights, affective dispositions and HR-decisions based on (increasing) individual discretion of managers (Demmke, 2019). In the field of Public Management, Human resource management (HRM) is gaining popularity, especially as regards a quantification and psychologization of research (Godard, 2014; Budds, 2019). "The field has moved away from a simple mechanistic view of the effects of emotions via their associated action tendencies to a more sophisticated, nuanced, and contingent view of how emotions contribute to behavior" (Godard, 2014). These trends towards the growing importance of individuals in HRM studies are in conformity with the growing popularity of micropolitics (Burns, 1961) in the field of organizational theory, and the attention to the concept of a society of "singularities" (Reckwitz, 2017) in the field of sociology. Diversity and identity politics have become popular in Political Sciences. According to Fukuyama (2018), universal concepts are being challenged by the rise of identity politics (Fukuyama, 2018, xvi); whereas new forms of recognition based on nation, religion, sect, race, ethnicity, or gender play an increasingly prominent role. In the field of organizational justice, expert's discussion focus on the responsibilities of people for their choices and the outcomes of their choices and whether new justice concepts should be made more sensitive to individual responsibility (Knight and Stemplowska, 2014). Take the case of the changing concept of equality and equity: Equality refers to a situation where everyone is given equal resources, whereas equity refers to achieving an equality of outcomes (that is, the resources are related to needs). Today, classical interpretations of both concepts are under pressure because of recent changes in the discourse about inequality and new discussions about another fundamental moral ideal in Western societies: people should be held personally responsible for the consequences of their choices (Greenfield, 2011). The idea of personal responsibility also seems to increasingly involve considerations of merit (choices, talent, and effort) and luck. Also perceptions of fairness and dignity are changing, employers and employees seem to re-evaluate distinctions between fair and unfair inequalities. As already mentioned, also public employees appear to relate fairness to some level of personal responsibility. And vice versa: Increasingly, employees are seen as responsible and called upon to be engaged, committed and continuously adapt their skills and competences. Thus, this change of (organisational justice) perceptions of values and principles has undeniably been fuelled by the growing influence of right-libertarian political views and the growing popularity of post-bureaucratic management reforms (Knight and Stemplowska, 2014, p. 1).

\section{The effects of the institutional turn on integrity}

The above-mentioned "affective", "behavioural" and "individualized" approaches can also be interpreted as counter-trends to the past: From rationality to bounded rationality, from hierarchical steering to individual discretion and job autonomy, from standardization to destandardisation, from central- 
ized concepts of fairness to individualized concepts of fairness and from ethical decision-making to bounded ethicality.

Behavioural economics and behavioural ethics (Bazerman and Tenbrunsel, 2011; Bazerman et al. 2015; Tenbrunsel and Chugh, 2015; OECD, 2018) are viewed as important and increasingly inform policymaking. Approaches that are based on standardized assumptions, law and compliance-based approaches are believed to be ineffective since they guard only against intentional forms of unethical behavior (and not unintentional forms). Behavioral public policy and behavioural ethics have also become popular because these concepts offer psychological explanations about organizational and individual failure (and because people overestimate their ability to do what is right and why they (may) act unethically without meaning to (Bazerman and Tenbrunsel, 2011; Ewert, 2020).

As such, these trends are to be welcomed because they illustrate the shortcomings of the classical institutional models. However, the increasing popularity of behavioral sciences in public policies and public ethics are leading toward an individualization of integrity policies and a focus on the concept of "public-officer ethics" (Kirby, 2020). These developments run counter to the discussed grand administrative tradition of the ethics of impartiality and compliance-based approaches. Instead, today's discourses focus on partiality, bounded awareness (Bazerman and Sezer, 2016) and value-based approaches. Consequently, the "bad apple" or "focus on the person as a root cause, is making a reappearance" (Tenbrunsel and Chugh, 2015, p. 207).

Behavioural approaches are also welcome as long as they do not lead to a new 'moral relativism' or the revision of rational thinking as such and the importance of classical instruments like rules, universal values and principles such as the rule of law and the importance of principles of administrative law are not being questioned. Moreover, new findings in the field are important as long as they do not only redress what philosophers (Immanuel Kant) or sociologists (such as Simon, 1997; Lindblom, 1990; Merton, 1936) said well before.

However, relativist approach to the principles of modern administration and rationality are emerging (Rutgers, 1999, p. 26), at least in some countries. According to Davies in Nervous States - How Feeling Took Over the World (Davies, 2019), we are entering a new era in which generalization and assumptions that there are laws, principles and values governing society as a whole and history as a whole, disappear (Davies, 2019, p. 162). Commitment to societal values, objectivity, impartiality and expertise increasingly mean old-fashioned group-thinking and the contrary of competition, speed and novelty. In the future, "the context for every life choice is that of competition, how to distinguish oneself from rivals, by qualification, image-seeking and management of oneself" (Davies, 2019, p. 169). Also, in the field of institutional integrity, some trends are even towards "spectacular outbursts of irrationality" (Smith, 2019, p. 7). An important part of the story of how we arrived here seems to be the collapse of traditional safeguards for the preservation of rational procedures and deliberation...." (Smith, 2019, p. 18). 
At this point, it makes sense to refer back to the beginnings of our discussions and the definition of modern public institutions as depersonalised systems that differ from traditional modes of "personalised" government. Could it be that we return and move back to personalised modes of post-modern government?

If this analysis is correct, it is time to re-consider the pros and cons of - at least - some traditional and (post-) modern institutional features (and defend rationality against irrationality and principles against moral- and cultural relativism). After all, if rationality is dismissed and universal values are rejected, then institutional ethics will be grounded on something arbitrary and modern principles are becoming relative. These trends seem to give us the freedom to go with any epistemic principle we choose (Lynch, 2017, p. 223). So, what could this concept of rational institutional integrity be?

Here, we are moving back to our philosophical discussion at the beginning of our deliberations: While it is true that the shift towards a bounded rationality framework may provide scholars with more realistic models of political decision-making (Shannon and Zachary, 2019), it should not lose interest in the link between integrity and the sociopolitical context and power relations. Overall, public institutions must remain spaces of reasons and stick to those administrative principles that are still important, such as the principles of rule of law, impartiality, equity and fairness.

\section{The expansion of the meaning of institutional integrity - new complexities and new confusion}

In the meantime, almost everywhere, countries have expanded the meaning of the concept of institutional integrity. Governments invest in ethics policies and in fighting unethical behavior more resources than ever before. In many cases, governments have institutionalized ethics infrastructures as a reaction to political scandals and started to focus on the implementation of ethics policies. Overall, ethics policies have become wider, broader, stricter, better institutionalized and professionalized. According to the above-mentioned study for the European Parliament, trends are towards a) more ethics rules and standards per country, b) "ethicalisation of rules" (more rules include references to ethics and ethical standards), c) the broadening of ethical definitions and d) towards stricter ethical standards. Moreover, purpose-driven, value driven management approaches and public value management tools such as scorecards are high on the agenda. Overall, talking about the need to change corporate- and administrative culture via the implementation of values and principles has also become important but also trendy and fashionable and - following an utilitarian perspective - an effective marketing tool. In some cases, greedy institutions (Coser, 1974) and moral entrepreneurship inform employees how to behave (Anderson, 2017), place a stronger emphasis on intrinsic motivators and ask employees to be engaged, committed and value driven.

While evidence is indeed mounting that the nature of integrity policies is strongly related to changing cognitive and cultural patterns, significant meth- 
odological and theoretical challenges still exist, especially in regard to the evaluation of the effectiveness of ethics policies.

For example, experts agree on the importance of ethical leadership for integrity. However, it is difficult to measure ethical leadership. Moreover, from a manager's point of view, daily management is about managing conflicts and value dilemmas under high time pressure and financial constraints. From a managerial perspective, ethical leadership is a virtue which is difficult to realize in practice. Consequently, "dark leadership" is not going away easily.

As regards the effectiveness of ethics policies, methodologically, there is also no consensus regarding the various policies, instruments and mechanism and how they impact on ethical outcomes. Whereas sound empirical knowledge exists about the positive link between meritocratic structures and levels of corruption and politicization, too little evidence exists regarding the link between flexible Governance trends, HR-reforms, destandardisation, individualization and the impact on ethical leadership and organizational justice and fairness perceptions. Therefore, more empirical studies and more non-ideological deliberations are sorely needed if we are to better understand ethical promises, paradoxes, challenges, and limitations. One of these challenges is to understand how institutions are changing and how this affects institutional integrity and workplace behavior.

As we have seen, the institutional context of public ethics policies is continuously changing, but whether it is changing to the better is not easy to say (Mackenzie, 2002). Instead, the conviction grew that there is no truth, objectivity, and rationality, but instead diversity, best-fit, context, contingency, nominalism, bounded rationality, and individualism. The problem with this trend towards relativism and destandardisation is the parallel decline of universal standards and basic moral principles. This popularity of moral relativism easily deprives of moral confidence, of the sense that we are right to condemn the actions of wrongdoers, and relativism removes the sense of conflict between apparently conflicting moral judgments that since they are relative, they do not really conflict, or the conflicts don't really matter (Lukes, 2008, p. 18).

At the same time, ministers and top-officials are subject to constant public and media scrutiny and (an exponential rise of) ethical and moral scandals. These scandals trigger discussions about trust. While it can be doubted that holders of public office have become more unethical as such, a generalised and inflated use of the term moral scandal, the increased (digital) media visibility of scandals, and the political abuse of moral issues have negative side-effects on trust perceptions. As a consequence, anti-corruption and moral campaigns against the elites have helped populists far more than it has helped politicians genuinely committed to fighting anti-corruption and conflicts of interest (Mungiu-Pippidi, 2020, p. 100).

The above mentioned study notes a relationship between Good Governance and the acceptability of corruption. As such, in countries with a higher democracy index, there is also less acceptance for corruption. Or, vice versa: In coun- 
tries where the democracy index is lower, the acceptance for corruption is also higher. These findings are important because they allow for the conclusion that the acceptance of unethical conduct is higher in countries with a lower democracy index and lower in countries with a higher democracy index. Thus, if countries want to take the fight against unethical behaviour and corruption seriously, an important precondition for this is to - simultaneously - maintain or strengthen systems of good governance. We also note the same logic as regards the situation of the rule of law. The higher the rule of law index of a country, the less acceptance for corruption. Or vice versa: The lower the rule of law index in a country, the higher is the acceptance for corruption. Thus, there exists a positive relationship between Government Integrity and unacceptability of corruption. As such, this confirms the hypotheses that Good Governance and "ethics pay off". Moreover, the institutionalisation of ethics policies can be expected to lower tolerance for unethical conduct. From this, we also draw the conclusion that adoption rules and policies are not enough. Instead, it is important to invest in integrity policies and good governance policies. Of course, these findings are not new. More important is the (empirical) confirmation that effective integrity policies pay off in terms of satisfaction with the functioning of the democratic system. If people trust in the effectiveness of ethics policies, they are also likely to trust the public institutions and the political system, which is based on Good Governance principles. Apparently, there is a trade-off between the growing complexity of our societies, the need for more, better, clearer, and stricter rules and the increasing number of violations. "There are many more laws to be broken nowadays, prosecutors have become more zealous, and resources at their disposal have become more plentiful." (Thompson, 2006, p. 163).

Moral and ethical standards are also changing more rapidly than before. What was legal a generation ago is considered unethical today. As discussed, regulation in the field of conflict of interests also takes a stronger prophylactic approach. Prohibitions are regulated for an increasing variety of circumstances. Requirements for disclosure of interests have shifted from an (original) concentration on financial issues into other non-pecuniary commitments. Also, public opinion has shifted towards an objective conception of conflict and a subjective conception of personal interests. Finally, media coverage about scandals has dramatically increased and, thus, supports views that unethical behaviour is increasing.

Therefore, it is becoming ever more difficult to call for more rational approaches in the field of integrity and to question the ever-more, ever stricter = ever - better logic in the field.

In fact, there is no easy answer as to whether we have too much or too little ethics or what the precise impact of specific instruments is on trust, democracy, effectiveness, efficiency, performance and behaviour. At least, recent trends indicate a growing interest in evaluating the institutionalisation of ethics and in the right design of ethics infrastructures. 
Thus, the concept of 'Integrity of Governance' is more complex than ever. Progress in the field is combined with new challenges, conflicts and dilemmas. As already mentioned, different experts observe trends are moving towards a "marketisation of societies", the return of the Leviathan, developments towards flexible forms of Governance, the emergence of a digitalized shared economy and a return to 'moral politics' - all in one. To this should be added trends to a diversification of institutional systems and organizational structures. This together presents a highly contradictory scenario.

\section{Diverging opinions: Towards best fit- or best-practice institutional integrity?}

Another trend make it more difficult to define institutional integrity from a public management perspective. One reason for this is the fragmented nature of approaches and the proliferation of integrity concepts and theories. Overall, academic publications about institutional integrity are becoming more complex (Schwartz, Harris and Comer, 2015; Kirby, 2020). According to Breaky, Cadman and Sampford (2015, p. 3), Sampford was actually the first academic to distinguish between institutional and individual integrity. Since then, Hoekstra and Kaptein are the leading experts in the field of institutionalising (public service) ethics. Also related to the issue of institutional integrity, Cropanzano and Folger (1991) were the first to invent the term of organizational justice and Linda Trevino the concepts of unethical behavior in the workplace and ethical culture (Trevino 1986). In the private sector, the concept of managerial ethics was founded by Schminke (1998). The notion of integrity systems seems to originate in the works by Jeremy Pope, the founder of Transparency International (Pope, 1996). Other concepts discuss organizational ethics integrity (Polowczk, 2017) or Handbooks on ethics infrastructure concepts (such as those published by the OECD, 2020). As regards the latter, the most important distinction between integrity systems (Huberts, Anecharico and Six, 2008, 2012) and ethics infrastructures seems to be that the former is a more technical concept and the latter relies on a discussion of much broader variables such as the importance of the rule of law, democracy and the judiciary (Fernandez and Camacho 2016; Martin and Kish-Gephart, 2014). Finally, according to the OECD (Maesschalck and Bertok, 2009) the concept of integrity management can be defined as the activities undertaken to stimulate and enforce integrity and prevent corruption and other integrity violations within a particular organization. Integrity management is the sum of systematic and integrated efforts to promote integrity within public-sector organizations (Kaptein, 1998).

"By definition, integrity management requires an integrated, systematic and coherent approach. Integrity instruments and initiatives are more effective when they are part of a systematic style (Van Tankeren, 2010). Although the importance of such a concerted approach seems almost a matter of course, this is not yet the case in many public organizations (Bowman 1990; Lawton et al. 2013). (...) Second, integrity management suffers from implementation 
deficiencies. Integrity policies have repeatedly proven to be a somewhat paper issue that has not received a direct follow-up (Transparency International, 2012; Van Den Heuvel and Huberts, 2003). (...). (...). Third, it appears to be difficult to find a balanced integrity management approach combining both compliance and integrity strategies (Paine, 1994)" (Hoekstra and Heres, 2016).

Much of the literature assumes that institutional integrity systems constitute 'best practice' and are universally applicable management. The best-practice approach is based on the belief that ethics institutions and infrastructures can be used in any organisation and the view that all organisations can improve ethical performance if they identify and implement best practices. According to Huberts (2014), it is possible to stress the 'basics of an integrity system' (Huberts, 2012, p. 190): Suggested instruments include rules, disciplinary policies, standards, codes of ethics, codes of standards, value management, ethical leadership, whistleblowing, job rotation, risk analysis, training, integrity plans, integrity monitoring, scandal management, registers, disclosure policies, ethical climate surveys, self-assessments, integrity officers, ethics committees and good working conditions. It is also widely accepted that preconditions of effective ethics infrastructures include openness and independent control mechanisms because principles of ethics cast suspicion on any process. In the meantime, there is also considerable consensus on what constitutes bad practices, for example, the absence of free media and independent judicial systems, high levels of politicization, poor leadership, unfair HR policies, lack of training, unprofessional performance measurement etc. in which holders of Public Office and public officials discipline themselves.

Despite this listing of ingredients of integrity systems, the increasing interest in institutional integrity has not necessarily produced more clarity and consensus on the effectiveness of ethics policies in different contexts and the right choice of policy instruments within the best-fit design of ethics infrastructures. More work is also needed as regards what types of incentives, or sanctions and enforcement practices work best to create motivation for responsible behaviour. Finally, it is unclear what kind of institutional integrity systems works best in different sectors and for different holders of public office (for example, independent and outside control is still rare in the case of parliaments).

Since discussions on ethics were dominated for a long time by bureaucratic, rational and legal approaches, there is also uncertainty about the need for and the effectiveness of other instruments, the right instrument mix, the role of self-regulation, and the relationship to other political, psychological and economical approaches. Again, others point to the need for more intrinsic incentives for doing good and warn against a too strong focus on compliance approaches. Here the focus shifts back on forth between those who wish to design sound organizational structures and coherent integrity management in order to tackle the individual causes of unethical behavior whereas others believe that it is important to focus on organizational causes. Especially, the development of conflicts of interest- and disclosure policies raises the questions as to the clarity of concepts, definitions, and who monitors, supervises 
and control the various "conflicts" and "interests" (Stark, 2000). This question is closely linked to the question whether and how public administrations manage and monitor integrity policies as such.

Institutionalization (Hoekstra and Kaptein, 2012) is an important aspect of integrity management and addresses the question of how these concerted efforts are thoroughly secured, anchored, embedded or safeguarded within the organization. Hoekstra "point out that there are two approaches to embed integrity measures within organizations: informal and formal institutionalization (Brenner, 1992). The nature of the informal approach is implicit, indirect and concerns less visible and tangible organizational aspects that, while affecting the ethical climate of the organization, are not primarily targeting ethics. This could include the behaviour of supervisors, the creation of shared values, fair remuneration, appraisal and promotion systems, and rewarding 'good' behaviour". The formal approach is, however, explicit, direct and visibly aimed at promoting ethical behaviour within organizations (Tenbrunsel et al., 2003).

At present, several reform trajectories exist which lead to innovations in the field of integrity management, but these highlight the existence of alternative models rather than a shift towards one common institutional reform model in the field of integrity. As already discussed, the search for a best-practice ethics infrastructure is confronted with a context and institution-based, fragmented-, situational and pragmatic reality. Overall, institutional differences - notably the levels of budgetary resources, social legitimacy, work systems, labour markets, education and training systems, work organisation and the collective organisation of employers and employees - mediate the impact of converging processes. Also, causes for unethical behavior may be found at individual, organizational, cultural- or societal level. Consequently, remedies, too, differ from case to case.

Consequently, the proposition for implementing institutional and organisational models such as ethics management systems and infrastructures is ambiguous. As discussed earlier, the political and institutional world is currently moving away from universal best-practice institutional configurations towards more specific best-fit and individualized context-related models. New developments lean more towards the testing of new organisational models and work systems that fit into the national, regional, local or even organisational and leader-follower context. Best fit schools are associated with this contingency approach and argue that organisations must adapt their strategies and implement reforms to the specific local strategy and to its environment. Thus, in most countries, the effectiveness of any particular institutional integrity system will be determined by the degree of consistency amongst its constituent elements and the way they fit into the specific culture, organisation, climate and leadership styles. Consequently, also the choice of policy instruments should be seen as a pluralist, non-deterministic and multipurpose approach that allows the application of behavioural insights 'throughout the policy process', but always in combination with (classical) policy instruments that address individual, organisational and systemic causes for unethical behavior (Ewert, 2020). 


\section{Christoph Demmke}

It is interesting to note that academic discussions in the field of institutional integrity have also turned away from the 'grand old' dichotomy: value-based approaches versus compliance-based approaches. In the meantime, also socalled "value based" countries wonder why new institutional designs and the search for "full integrity" did not produce the desired (superior) results. For example, Andersson claims for Sweden that corruption and conflicts of interest vulnerabilities have increased (Andersson, 2019, p. 9). Hoekstra notes that - despite being an international forerunner in the field of integrity - the Netherlands focus on economic values than all other countries and financial constraints and saving measures had a negative impact on integrity polices. In the meantime, also in all Nordic States, mediated ethical scandals and the "personalization of politics" have become a standard feature of political life, even as regards minor offences and small deviant actions (Pollack et al., 2018). As such, the relationship between public institutions and integrity is full of conflicting interests. It is not a love affair (Ortman, 2015, p. 72). However, the concept of institutional integrity is becoming ever more complex and separated from other institutional logics.

\section{Conclusions}

For a long time the concept of institutional integrity formed an integrated part of the bureaucratic concept. During the past decades, new ideas and concepts about institutional integrity are emerging. Today, concepts are expanding as a separate public policy. Differently to the past, they are also disconnected from modern public management concepts. As Thompson noted decades ago: "We should not expect the rules of government ethics to be simple or to become simpler in the future. As government has become more complex, government ethics (...) are also likely to become more complex" (Thompson, 1992, p. 254).

Whereas traditional "integrated" bureaucratic logics failed, even the best new institutional integrity design only fill the gaps that other public policies and (managerial) system logics produce. Many countries are good at filling some gaps, or even many. However, recent trends in the field of rule of law, justice, freedom of press, politicization, corruption and conflicts of interests show worrying trends in the respective fields (even if we consider that it is difficult to measure these issues). All of these issues influence integrity and institutional integrity. And, vice versa.

As current concepts of integrity policies focus on the misconduct of individuals (and not, for example, of organisations), the management of integrity policies requires sophisticated and complex interventions and high expertise of those who are in charge of monitoring the conduct of the individuals working inside the institutions. However, overall, individualised monitoring is difficult, complex, time consuming and - increasingly - costly. Because the management of integrity policies is becoming ever more complex and individualised, it is time to raise the question of whether or not it would be more effective to move from an individual "bad apple" approach to an institutional integrity 
approach. Should, for example, the severity of integrity violations be judged by the impact and importance of the cases?

Also, from a governance approach, institutional integrity is a 'plug-in policy' that fills the gaps that other policies and other governance logics produce. It seems that different system logics in economy, law, politics and sciences contradict with each other. Consequently, progress in institutional integrity is not translated into more effectiveness of ethics standards as other system imperatives generate reform outcomes that are in conflicts with objectives of ethics policies. As such, also the field of public management is about managing conflicting objectives and values. The problem is clearly not with behavioural ethics nor with individualised approaches, but with individualisation and (moral) relativism as a trend becoming the dominant approach to understanding the very complex world of organisational behaviour and public service ethics. The problem is rather that expanding integrity policies should "repair" conflicting management logics. They can not. 


\section{References}

Adams, G. and Balfour, D. (1998). Unmasking Administrative Evil. Thousand Oaks: Sage.

Anderson, E. (2017). Private Government. How Employers Rule our Lifes. Princeton: University Press.

Anechiarico, F. and Jacobs, J. B. (1996). The Pursuit of Absolute Integrity. Chicago and London: The University of Chicago Press.

Aquino, K. and Americus, R. (2002). The Self-Importance of Moral Identity. Journal of Personality and Social Psychology, 83(6), pp. 1423-1440.

Bazerman, A. T. and Chugh, D. (2015). Behavioural ethics: a story of increased breadth and depth: Current Opinion in Psychology, pp. 205-210.

Bazerman, M.H. and Tenbrunsel, A.E. (2011). Blind Spots. Princeton: University Press.

Bazerman, M.H. and Ovul S. (2016). Bounded awareness: Implications for ethical decision-making. Organizational Behavior and Human Decision Processes, 36, pp. 93-105.

Bingham, T. (2011). The Rule of Law. London: Penguin.

Breaky, H., Cadman, T. and Sampford, C. (2015). Conceptualizing Personal and Institutional Integrity: The Comprehensive Integrity Framework.

Brooke, N. S., Zachary, Mc Gee. and Bryan D. J. (2019). Bounded Rationality and Congnitive Limits in Political Decision-Making. Oxford Research Encyclopedia Politics. DOI: 10.10193/acrefore/9780190228637.013.961.

Budds, J. (2019). The psychologicisation of employment relations, alternative models of employment relationships, and the OB turn. Human Resource Management Journal. DOI: 10.1111/1748-8583.12274.

Christensen, T., Laegreid, P. and Arne Rovik, K. (2020). Organizing Theory and the Public Sector. New York: Routledge, $2^{\text {nd }}$ edition.

Comer, D. (eds.). (2015). The Ethical Contribution of Organizations to Society. Emerald: Bingley, pp. 1-40.

Burns, T. (1961). Micropolitics: Mechanisms of Institutional Change. Administrative Science Quarterly, 6(3), pp. 257-281.

Carpintero, H. (2017). History of Organizational Psychology. Organizational and Institutional Psychology. DOI: 10.1093/acrefore/9780190236557.013.39.

Coser, L. (1974). Greedy Institutions, Patterns of Undivided Commitment. New York: Free Press.

Cropanzano, R. and Folger, R. (1991). Procedural Justice and Worker Motivation. In Steers and Porter, eds., Motivation and Work Behavior. New York, pp. $131-143$.

Dahlström, C., Lapuente, V. and Teorell, J. (2012). The merit of meritocratization: Politics, bureaucracy, and the institutional deterrents of corruption. Political Research Quarterly, 65(3), pp. 656-668.

Dahlström, C. and Lapuente, V. (2017). Organizing Leviathan: Politicians, bureaucrats, and the making of good government. Cambridge, U.K.: Cambridge University Press.

Davies, W. (2019). Nervous States - How Feeling Took Over the World. London: Vintage. 
Demmke, C. (2019). The Legitimacy of Civil Services in the 21st Century. In Oxford Encyclopedia of Politics. Oxford University Press. DOI: 10.1093/ acrefore/9780190228637.013.982.

Demmke, C. (2019). Governance Reforms, Individualization of Human Resource Management (HRM), and Impact on Workplace Behavior-A Black Box? Public Integrity. DOI: 10.1080/10999922.2019.1656960.

Di Maggio, P.J. and Powell, W.W. (1983). The iron cage revisited: Institutional isomorphism and collective rationality in organizational fields. American Sociological Review, 48, pp. 147-160.

European Parliament. (2020). The Effectiveness of Conflict of Interest Policies and Practices for Ministers and Top-officials in the Member States of the European Union. Study for the European Parliament, PE 651.697. Brussels/ Luxemburg.

Ewert, B. (2020). Moving beyond the obsession with nudging individual behaviour: Towards a broader understanding of Behavioural Public Policy. Public Policy and Administration, 35(3), pp. 337-360.

Friedman, M. (1970). The Social Responsibility of Business is to Increase Its Profits. New York Times Magazine, 13 September 1970.

Fernandez, J. L. and Camacho, J. (2016). Effective elements to establish an Ethical Infrastructure: An Exploratory Study of SME's in the Madrid Region. Journal of Business Ethics, 138, pp. 113-131.

Fukuyama, F. (2018). Identity. London: Profile Books.

Glavas, A. and Radic, M. (2019). Corporate Social Responsibility: An Overview from an Organizational and Psychological Perspective. Organizational and Institutional Psychology. DOI: 10.1093/acrefore/9780190236557.013.90.

Godard, J. (2014). The psychologisation of employment relations? Human Ressource Management Journal, 24, pp. 1-18.

Heywood, P. (2017). Rethinking Corruption: Hocus-Pocus, Locus and Focus. The Slavonic and East European Review, 95(1), pp. 21-48.

Hoekstra, A. and Muel, K. Ethics Management: A Pluralistic and Dynamic Perspective, unpublished.

Hoekstra, A. and Kaptein, M. (2012). The Institutionalization of Integrity in Local Government. Public Integrity, 15(1), pp. 5-28.

Hoekstra, A. and Kaptein, M. (2014). Understanding integrity policy formation process: A case study in The Netherlands of the conditions of change. Public Integrity, 16(3), pp. 243-263.

Hoekstra, A. and Heres, L. (2016). Ethical Probity in Public Service. In A. Farazmand, ed., Global Encyclopedia of Public Administration, Public Policy, and Governance. Springer International Publishing Switzerland. DOI: 10.1007/978-3-319-31816-5_922-1

Hoekstra, A. (2015). Institutionalizing Integrity Management, Challenges and solutions in times of financial crises and austerity measures. In A. Lawton, Z. van der Wal and L. Huberts, eds., Ethics in Public Policy and Management. London: Routledge, pp. 151-152.

Hood, C. and Dixon R. (2013). A Model of Cost-Cutting in Government? The Great Management Revolution in UK Central Government Reconsidered. Public Administration, 91(1), pp. 114-134.

Huberts, L., Anechiarico, F. and Six, F.E. (eds.) (2008). Local Integrity Systems: World Cities Fighting Corruption and safeguarding Integrity. Den Haag: BJU. 


\section{Christoph Demmke}

Huberts, L. and Six, F.E. (2012). Local Integrity Systems, Towards a Framework for Comparative Analysis and assessment. Public Integrity, 14(2), pp. 151-172.

Huberts, L. (2014). The Integrity of Governance. London: Palgrave Macmillan.

Kaptein, M. (1998). Ethics Management. Dordrecht: Kluwer.

Kieran, T. et al. (2010). Reaffirming Legal Ethics. London: Routledge.

Kirby, N. (2020). (forthcoming). An Institution-First Conception of Public Integrity. British Journal of Political Science.

Knight, C. and Stemplowska, Z. (eds.) (2014). Responsibility and Distributive Justice, Oxford: Oxford University Press.

Kolthoff, E.W. (2007). Ethics and New Public Management. Empirical research into the effects of Businesslike Government on Ethics and Integrity. Den Haag: BJU.

Lan, J. E. (2014). Institutionality: "Institution" and "Institutions Matter". Open Journal of Political Science. 4(1), pp. 23-30.

Lindblom, C. E. (1990). Inquiry and Change. New Haven, London: Yale University Press.

Lynch, M.P. (2017). Reasons for Reasons. In P. Catapano and S. Critchley, ed., Modern Ethics in 77 Arguments. Liveright, New York, London, pp. 222-229.

Lukes, S. (2008). Moral Relativism. New York: Picador.

Mackenzie, G.C. (2002). Scandal Proof, do ethics laws make government ethical? Washington D.C: Brookings Institution.

Maesschalck, J. and Bertok, J. (2008). Towards a Sound Integrity Framework, instruments, processes, structures and conditions for implementation. Paris: OECD.

Martin, S., Kish-Gephart, J. and Detert, J. (2014). Blind Forces: Ethical Infrastructures and moral disengagement in organizations. Organizational Psychology Review, 4(4), pp. 295-325.

Merton, R. (1936). The Unanticipated Consequences of Purposive Social Action. American Sociological Review, 1(6), pp. 894-904.

Merton, R. (1987). Bureaucratic structure and personality. In J. M. Shafritz and A. C. Hyde, eds., Classics of Public Administration ( $2^{\text {nd }}$ ed). Chicago, IL: The Dorsey Press.

Molina, C., Cropanzano, R. and Martinez-Tur, V. (2017). Organizational Justice. New York: Routledge.

Mungiu-Pipidi, A. (2020). The Rise and Fall of Good-Governance Promotion. Journal of Democracy, 31(1), pp. 88-102.

Nieuwenburg, P. (2007). The Integrity Paradox. Public Integrity, 9(3), pp. 213224. DOI: 10.2753/PIN1099-9922090301.

OECD (2017). Preventing Policy Capture - Integrity in Public Decision-Making. Paris: OECD.

OECD (2018). Behavioural Insights for Public Integrity. Paris: OECD.

OECD (2019). Governance at a Glance 2019. Paris: OECD Publishers.

OECD (2020). OECD Public Integrity Handbook. Paris: OECD Publishers.

Ortmann, G. (2015). Organisation und Macht. Weilerswist: Velbrueck Wissenschaft, $2^{\text {nd }}$ edition.

Paine, L.S. (2000). Does Ethics Pay? Business Ethics Quarterly, 10(1), pp. 319-330. 
Pollack, E. et al. (2018). The New Normal: Scandals as a standard feature of political life in Nordic Countries. International Journal of Communication, 12, pp. 3087-3108.

Pope, J. (1996). National Integrity Systems. The TI Sourcebook. Berlin: Transparency International.

Polowcyk, P. (2017). Organizational ethical integrity: good and bad illusions. Open access Palgrave Publications. DOI: 10.1057.

Raadschelders J.C.N. et al. (2015). Civil Servants in the Enabling Framework State of the $21^{\text {st }}$ Century. In Van der Meer F.M. et al., eds., Comparative Civil Service Systems in the $21^{\text {st }}$ Century. Palgrave Macmillan, London.

Rauch, J., and Evans, P. (2000). Bureaucratic structure and bureaucratic performance in less developed countries. Journal of Public Economics, 75, pp. 49-71.

Reckwitz, A. (2017). Die Gesellschaft der Singularitäten. Frankfurt/M.: Suhrkamp.

Rothstein, B. (2012). Good Governance. Oxford Handbook of Governance. DOI: 10.1093/oxfordhb/9780199560530.013.0010.

Rutgers, M. (1999). Be rational! But what does it mean? Journal of Management History, 5(1), pp. 17-35.

Schwartz, M., Harris. H.and Comer, D. (eds.) (2015). The Ethical Contribution of Organizations to Society. Emerald: Bingley.

Saint M. and Thompson, F. (eds.) (2006). Public Ethics and Governance: Standards and Practices in Comparative Perspective. Amsterdam: Elsevier.

Schminke, M. (1998). Managerial Ethics: Moral Management of People and Processes. Lawrence Erlbaum.

Shannon, B.N., McGee, Z. A. and Jones, B. D. (2019). Bounded Rationality and Cognitive Limits in Political Decision Making. DOl: https://doi.org/10.1093/ acrefore/9780190228637.013.961

Simon, H. (1997). Administrative Behaviour, $4^{\text {th }}$ edition. New York: Free Press.

Smith, J. E. (2019). Irrationality. Princeton, Oxford: Princeton University Press.

Stark, A. (2000). Conflict of Interest in American life. Harvard University Press, Cambridge.

Tenbrunsel, T. A. and Chugh, D. (2015). Behavioral ethics: A story of increased breadth and depth. Current Opinion in Psychology, 6, pp. 205-210. DOI: 10.1016/j.copsyc.2015.08.022.

Tevino, L. (1986). Ethical Decision Making in Organizations: A Person-Situation Interactionist Model. The Academy of Management Review, 11(3)3, pp. 601-617.

Thompson, D. (1985). The Possibility of Administrative Ethic. Public Administration Review, 45(5), pp. 555-561.

Thompson, D. (1992). Paradoxes of Governance Ethics. Public Administration Review, 52(3), pp. 254-259.

Van der Meer, F., Raadschelders, J. And Toonen, T. (eds.) (2015). Comparative Civil Service Systems in the $21^{\text {st }}$ Century. Palgrave MacMillann. 